\title{
CFD Investigation into Seakeeping Performance of a Training Ship
}

\author{
Ahmad Fitriadhy ${ }^{1,}{ }^{*}$, Syarifuddin Dewa ${ }^{2}$, Nurul Aqilah Mansor ${ }^{3}$, Nur Amira Adam ${ }^{3}$, Cheng Yee $\mathrm{Ng}^{4}$, \\ Hooi Siang Kang ${ }^{5}$
}

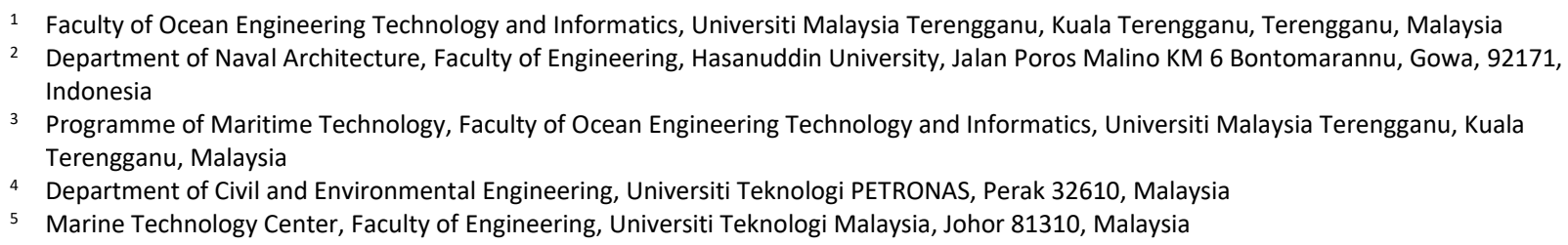

3 Programme of Maritime Technology, Faculty of Ocean Engineering Technology and Informatics, Universiti Malaysia Terengganu, Kuala Terengganu, Malaysia

4 Department of Civil and Environmental Engineering, Universiti Teknologi PETRONAS, Perak 32610, Malaysia

5 Marine Technology Center, Faculty of Engineering, Universiti Teknologi Malaysia, Johor 81310, Malaysia

\section{ARTICLE INFO}

\section{Article history:}

Received 22 November 2020

Received in revised form 16 January 2021

Accepted 23 January 2021

Available online 30 January 2021

\section{Keywords:}

Seakeeping; heave; pitch; wavelength; speed; wave direction; CFD

\section{ABSTRACT}

The numerous ship accidents at sea have usually resulted in tremendous loss and casualties. To prevent such disastrous accidents, a comprehensive investigation into reliable prediction of seakeeping performance of a ship is necessarily required. This paper presents computational fluid dynamics (CFD) analysis on seakeeping performance of a training ship (full scale model) quantified through a Response of Amplitude Operators (RAO) for heave and pitch motions. The effects of wavelengths, wave directions and ship forward velocities have been accordingly taken into account. In general, the results revealed that the shorter wavelengths $(\lambda / L \geq 1.0)$ have insignificant effect to the heave and pitch motions performance of the training ship, which means that the ship has good seakeeping behavior. However, the further increase of wavelength was proportional with the increase of RAO for her heave and pitch motions; whilst it may lead to degrade her seakeeping quality. In addition, the vertical motions behavior in the following-seas dealt with higher RAO as compared with case of the head-seas condition. Similarly, the subsequent increase of the ship forward velocity was prone to relatively increase of the RAO for her heave and pitch motions especially at $\lambda / L \geq 2$.0. It was merely concluded that this seakeeping prediction using CFD approach provides useful outcomes in the preliminary design stage for safety assessment of the training ship navigation during sailing.

\section{Introduction}

Currently, Department of Education and Culture, South-Sulawesi province, Indonesia has successfully awarded three training ships to Vocational High-School of Fishery and Nautical Science

\footnotetext{
* Corresponding author.

E-mail address: naoe.afit@gmail.com (Ahmad Fitriadhy)
}

https://doi.org/10.37934/cfdl.13.1.1932 
in Makassar. Primary role of these training ships is purposely designed to train students/cadets through providing best practice experiences to be sailors/seafarers. However, numerous marine accidents which occurred in the recent years have caused a significant increase of interest in the problems of safe operations for a training ship (Ryu et al., [1] and Cho \& Lee [2]). Merely, the growing awareness of the navigational safety especially in the harsh conditions leads to an investigation on the sea-worthiness quality of the current training ships, which is able to predict their worst seakeeping scenarios in a realistic seaway.

Several research investigations on the ship seakeeping behaviour in waves, which affects her ability to remain at sea in all conditions, have been basically resolved into the numerical and experimental approaches. Han et al., [3] and Han et al., [4] have simulated numerically and reported that the Motion Sickness Incidence (MSI) of the training ship led to discomfortability as the forward speed increased. In the perspective of ship design, Kim et al., [5] found experimentally that the heave and pitch motions reduced with the increase of the ship's length-to-beam ratio. Siddiqui et al., [6] presents a series of experiments with a damaged ship section in a small wave flume that affects the ship motion. Yao et al., [7] carried out the seakeeping analysis using the numerical and experimental models and concluded that the increase of the heave and pitch motions were proportional with the increased of the wavelengths. The similar results were also found by Habekost et al., [8]. Wang et al., [9] and Lin \& Lin [10] presented the nonlinear numerical analysis, where the heave and pitch motions were predominantly affected by the increase of the ship's speed and worsening of the sea-state as well as proven experimentally by $\mathrm{Bi}$ et al., [11]. Even so, the experimental method is a timeconsuming, complex procedure process and costly; and even impractical for various seakeeping test configurations. Meanwhile, the accuracy of the typical numerical approach requires necessarily further verification since some simplified simulation conditions were assumed to be given. Whilst a Computational Fluid Dynamic (CFD) approach for assessing the seakeeping performance on the training ship put very demanding requirements with regards to a more reliable result both of accuracy and precision (Fitriadhy \& Adam [12], Mancini et al., [13] and Chen et al., [14]). The rapid advancement in computers, the application of more sophisticated 3D-numerical modelling employed in naval architecture problems is possibly satisfied.

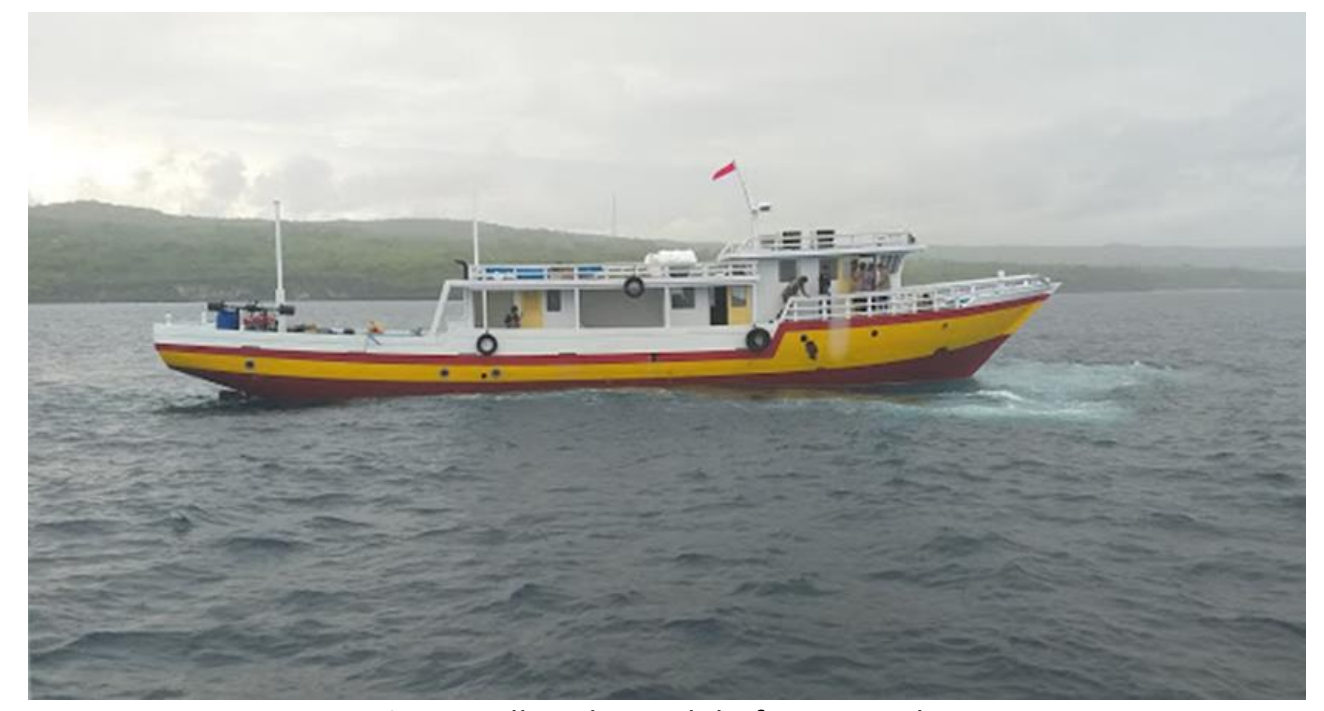

Fig. 1. Full-scale model of training ship

In the present study, a Computational Fluid Dynamics (CFD) investigation has been conducted to analyse the seakeeping performance of the training ship in full-scale dimension (as shown in Figure 1). It should be noted here that a magnitude of the dynamic heave motion responses presented in 
the form of Response of Amplitude Operators (RAO) of the training has been comprehensively quantified to predict her heave and pitch motions. This study has provided very interesting computational simulations, whilst a hydrodynamic description underlying the rationale behind the results is explained. To achieve this research objective, several parameters such as effect of various wavelengths, wave directions i.e., head and following seas; and ship's speeds have been primarily taken into accounts in the computational simulation. Here, the CFD software called as Flow-3D is employed through applying unsteady Reynolds-Averaged Navier-Stokes Equation (RANSE); which includes several techniques (TruVOF) to capture the free surface effect. The Response Amplitude Operator (RAO) of heave and pitch motion performances are then accordingly discussed.

\section{Governing Equation}

Here, the main equation use by the CFD regularly is Navier-Stokes equation, which basically includes continuity and momentum equations (Sapee [15]). Basically, two equations in accordance to the law conservation of mass and momentum as clearly expressed in Eqs. (1)-(4). The current CFD simulation is based on the incompressible unsteady RANSE, which employs the volume of fluid (VOF) to solve a free surface model.

\subsection{Continuity and Momentum Equation}

The general mass continuity equation presented in Eq. (1). The notation of $V_{F}$ is the fractional volume open to flow, $\rho$ is the fluid density, $R_{D I F}$ is a turbulent diffusion term, $R_{S O R}$ is a mass source and $A_{x}, A_{y}$ and $A_{z}$ is the fractional area open to flow in $\mathrm{x}, \mathrm{y}$ and z-direction, respectively. The coefficient of $\mathrm{R}$ is set to unity; whilst the value of $\xi=0$. The velocity components $(u, v, w)$ are in the coordinate directions $(x, y, z)$ or $\left(r, R_{S O R}, z\right)$, (User's Manual FLOW-3D 10.1.1 [16]):

$V_{F} \frac{\partial \rho}{\partial t}+\frac{\partial}{\partial x}\left(\rho u A_{x}\right)+R \frac{\partial}{\partial y}\left(\rho v A_{y}\right)+\frac{\partial}{\partial z}\left(\rho \omega A_{z}\right)+\xi \frac{\rho u A_{x}}{x}=R_{D I F}+R_{S O R}$

The momentum theory also applies in three fluid velocity components $(u, v, w)$ that has been used in the motion equation as displayed in Eqs. (2)-(4).

$$
\begin{gathered}
\frac{\partial u}{\partial t}+\frac{1}{V_{F}}\left\{u A_{x} \frac{\partial u}{\partial x}+v A_{y} R \frac{\partial u}{\partial y}+w A_{z} \frac{\partial u}{\partial z}\right\}-\xi \frac{A_{y} v^{2}}{x V_{F}} \\
=-\frac{1}{\rho} \frac{\partial p}{\partial x}+G_{x}+f_{x}-b_{x}-\frac{R_{S O R}}{\rho V_{F}}\left(u-u_{w}-\delta u_{s}\right) \\
\frac{\partial v}{\partial t}+\frac{1}{V_{F}}\left\{u A_{x} \frac{\partial v}{\partial x}+v A_{y} R \frac{\partial v}{\partial y}+w A_{z} \frac{\partial v}{\partial z}\right\}+\xi \frac{A_{y} u v}{x V_{F}} \\
=-\frac{1}{\rho}\left(R \frac{\partial p}{\partial y}\right)+G_{y}+f_{y}-b_{y}-\frac{R_{S O R}}{\rho V_{F}}\left(v-v_{w}-\delta v_{S}\right) \\
\frac{\partial w}{\partial t}+\frac{1}{V_{F}}\left\{u A_{x} \frac{\partial w}{\partial x}+v A_{y} R \frac{\partial w}{\partial y}+w A_{z} \frac{\partial w}{\partial z}\right\}=-\frac{1}{\rho} \frac{\partial p}{\partial z}+G_{z}+f_{z}-b_{z}-\frac{R_{S O R}}{\rho V_{F}}\left(w-w_{w}-\delta w_{S}\right)
\end{gathered}
$$

where $\left(G_{x}, G_{y}, G_{z}\right)$ are body accelerations, $\left(f_{x}, f_{y}, f_{z}\right)$ are viscous accelerations and $\left(b_{x}, b_{y}, b_{z}\right)$ are flow losses in porous media or across porous baffle plates, and the final condition account for the 
injection of mass at a source represented by a geometry element. The $u_{w}, v_{w}$ and $w_{w}$ are the velocity of the source components whereas the $u_{s}, v_{s}$ and $w_{s}$ are the velocity of the fluid at the surface of the source relative to the source itself. $\delta$ is the source of pressure where the statics pressure is applied in this research which determine the $\delta=1.0$, (User's Manual FLOW-3D 10.1.1 [16]).

\subsection{Ship Motion Equation}

Referring to geometry of body motion, the motion equations of a ship model is expressed in Eqs. (5)-(7):

$\frac{d}{d t}\left(m \vec{v}_{c}\right)=\vec{f}$

$$
\frac{d}{d t}\left(M_{c} \cdot \vec{w}_{c}\right)=\vec{m}_{c}
$$

The index $C$ shows the center of mass of the ship. $m$ and $M_{c}$ are the ship's mass and the tensor of her moments of inertia, respectively. The notations of $\vec{\omega}_{c}$ and $\vec{v}_{c}$ are the angular velocity and the velocity vectors of a ship, respectively. Meanwhile, $\vec{m}_{c}$ represents the resultant moment vector acting on the body (Maki et al., [17]). In addition, $\vec{f}$ is the resultant force which is expressed in Eq. (7).

$\vec{f}=\int_{S}(T-\rho I) \cdot \vec{n} d S+\int_{V} \rho_{b} \vec{b} d V+\vec{f} E$

Here, $\rho_{b}$ and $f \vec{E}$ are the density of the body and the external forces acting in the body, respectively (Yan \& Huang [18]). Here, the dynamic fluid body interaction function is applied to simulate the ship's vertical motion i.e., heave and pitch motions.

\subsection{Waves}

The seakeeping simulation of the ship has been assessed in regular waves, where the fifth-order Stokes wave's model is appropriately employed. The reference system $(x, z)$ is set, where $x$ (positive direction) is the wave propagation direction and $z$ (positive direction) in the upward direction. The wave properties such as wave height $(H)$, wavelength $(\lambda)$, and wave period $(T)$ have been taken into account in the simulation. Meanwhile, the equations of the angular wave frequency $(\omega)$ and the wave celerity $(c)$ are presented bellows.

$\omega=\frac{2 \pi}{T}=c k$ and $c=\frac{\lambda}{T}$

where $k$ is the wave number.

$k=\frac{2 \pi}{\lambda}$ 


\subsection{Turbulence Model}

For the stability and efficiency of the numerical computation, Renormalization-group (RNG) turbulence model has been applied by previous researchers such as Fitriadhy et al., [19], Fitriadhy et al., [20], Fitriadhy \& Malek [21] and Fitriadhy et al., [22] since it has wider applicability than the standard $\mathrm{k}-\varepsilon$ model. This turbulence model also has considered for low Reynolds number effects (Yakhot \& Orszag [23], Yakhot et al., [24], Koutsourakis et al., [25] and Li et al., [26]) which is known to more accurately describe low intensity turbulence flows with having strong shear regions.

\section{Simulation Condition}

\subsection{Principle Data of Ship}

The body plan of ship is clearly shown in Figure 2. The ship particulars consist of displacement and wetted surface area is presented in Table 1.

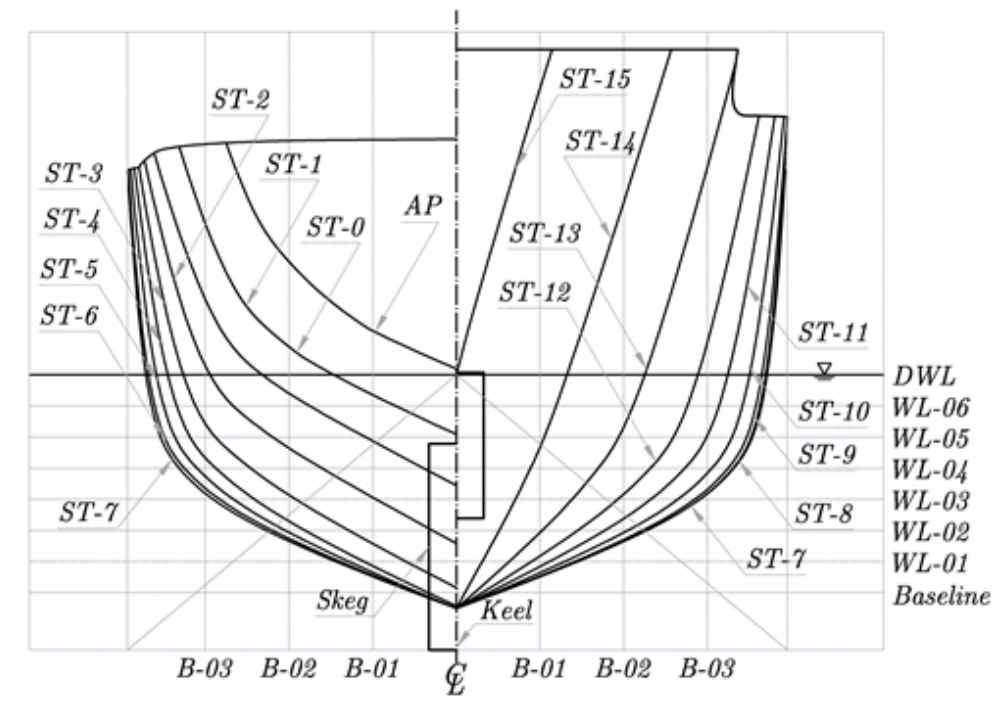

Fig. 2. Body plan of a training ship

Table 1

Ship particulars

\begin{tabular}{ll}
\hline Description & Value \\
\hline Length overall (LOA), $\mathrm{m}$ & 26.632 \\
Waterline Length (LWL), $\mathrm{m}$ & 23.500 \\
Beam, $\mathrm{m}$ & 3.975 \\
Draft Amidships, $\mathrm{m}$ & 1.400 \\
Immersed depth, $\mathrm{m}$ & 1.768 \\
Displacement, $\mathrm{t}$ & 69.590 \\
Wetted Surface Area, $\mathrm{m}^{2}$ & 138.726 \\
Block coefficient (Cb) & 0.411 \\
LCB length from amidships, $\mathrm{m}$ & -0.227 \\
KB, $\mathrm{m}$ & 0.819 \\
Immersion (TPc), tonne/cm & 0.734 \\
MTc, tonne.m & 1.047 \\
Ixx, $\mathrm{m}^{4}$ & 258464.300 \\
Ixz, $\mathrm{m}^{4}$ & 31988.090 \\
Iyy, $\mathrm{m}^{4}$ & 3555692.000 \\
$\mathrm{Izz}, \mathrm{m}^{4}$ & 3556243.000 \\
\hline
\end{tabular}




\subsection{Parametric Studies}

To achieve the objective, several parameters such as such as the effect of wavelengths within the range of $0.25 \mathrm{~L}<\lambda<3.0 \mathrm{~L}$, wave directions (head and following-seas) and various ship's speed (Vs) from $3.601 \mathrm{~m} / \mathrm{s}$ to $5.607 \mathrm{~m} / \mathrm{s}$, have been employed in the simulation, where the wave height of $1.0 \mathrm{~m}$ is assumed constant. The detailed simulation conditions are presented in Table 2.

Table 2

Computational simulation conditions

\begin{tabular}{|c|c|c|c|c|c|c|c|c|c|c|c|c|c|}
\hline \multirow{2}{*}{$V s(\mathrm{~m} / \mathrm{s})$} & \multicolumn{12}{|c|}{ Ratio of wavelength over ship length, $(\lambda / L)$} & \multirow{2}{*}{$\begin{array}{l}\text { Wave } \\
\text { direction }\end{array}$} \\
\hline & 0.25 & 0.5 & 0.75 & 1.0 & 1.25 & 1.5 & 1.75 & 2.0 & 2.25 & 2.5 & 2.75 & 3.0 & \\
\hline 3.601 & $\sqrt{ }$ & $\sqrt{ }$ & $\sqrt{ }$ & $\sqrt{ }$ & $\sqrt{ }$ & $\sqrt{ }$ & $\sqrt{ }$ & $\sqrt{ }$ & $\sqrt{ }$ & $\sqrt{ }$ & $\sqrt{ }$ & $\sqrt{ }$ & \\
\hline 4.630 & $\sqrt{ }$ & $\sqrt{ }$ & $\sqrt{ }$ & $\sqrt{ }$ & $\sqrt{ }$ & $\sqrt{ }$ & $\sqrt{ }$ & $\sqrt{ }$ & $\sqrt{ }$ & $\sqrt{ }$ & $\sqrt{ }$ & $\sqrt{ }$ & Head- \\
\hline 5.607 & $\sqrt{ }$ & $\sqrt{ }$ & $\sqrt{ }$ & $\sqrt{ }$ & $\sqrt{ }$ & $\sqrt{ }$ & $\sqrt{ }$ & $\sqrt{ }$ & $\sqrt{ }$ & $\sqrt{ }$ & $\sqrt{ }$ & $\sqrt{ }$ & \\
\hline 4.630 & $\sqrt{ }$ & $\sqrt{ }$ & $\sqrt{ }$ & $\sqrt{ }$ & $\sqrt{ }$ & $\sqrt{ }$ & $\sqrt{ }$ & $\sqrt{ }$ & $\sqrt{ }$ & $\sqrt{ }$ & $\sqrt{ }$ & $\sqrt{ }$ & $\begin{array}{l}\text { Following } \\
\text {-seas }\end{array}$ \\
\hline
\end{tabular}

\subsection{Computational Domain and Boundary Conditions}

The boundary conditions and computational domain are displayed in Figure 3. Three mesh blocks composing of the main block and two nested blocks are presented as shown in Figure 3 . The main mesh block with the boundary condition at $X_{\min }$ has been assigned as wave; while $X_{\max }$ is defined as the outflow boundary, which is purposed to avoid reverse flow. Meanwhile, the absorbing layer is set up to reduce reflection of periodic wave at an open boundary that works effectively in practice as seen in Figure 3(a). $Y_{\min }, Y_{\max }$ and $Z_{\min }$ are assigned as the symmetry boundaries, which they apply zero-gradient conditions; whereas $Z_{\max }$ is the specified pressure to create a uniform pressure in the boundary. In addition to the computational domain at the nested mesh blocks, all boundary conditions are set as the symmetries. These nested blocks are utilized to progressively refine the model mesh resolution without sharp discontinuities in cell size (User's Manual FLOW-3D 10.1.1 [16]). The detailed boundary conditions are completely displayed in Table 3.

The meshing generation is generated in Flow-3D as seen in Figure 3(b). A nested mesh block is added to increase the meshing quality for the ship model. The ship is assigned in two degrees of freedom which are heave and pitch motion. Here, the convergence computational result has been assessed to preserve the steadiness in the computational simulation results as presented in Table 4. Referring to this mesh independent results, the total cell meshing of 4,083,085 has been selected in all computational simulations of the training ship model. For this reason, it was unnecessary to increase the total cell meshing up to 5,809,868 due to its insignificant influence into the computational results of the magnitude of the heave and pitch motions amplitudes. Besides, the time history for the heave and pitch motions of the training ship at $\lambda=1.75 \mathrm{~L}$ is clearly presented in Figure 4. The visualisation of the ship is then displayed using Flow-Sight as seen in Figure 5. 


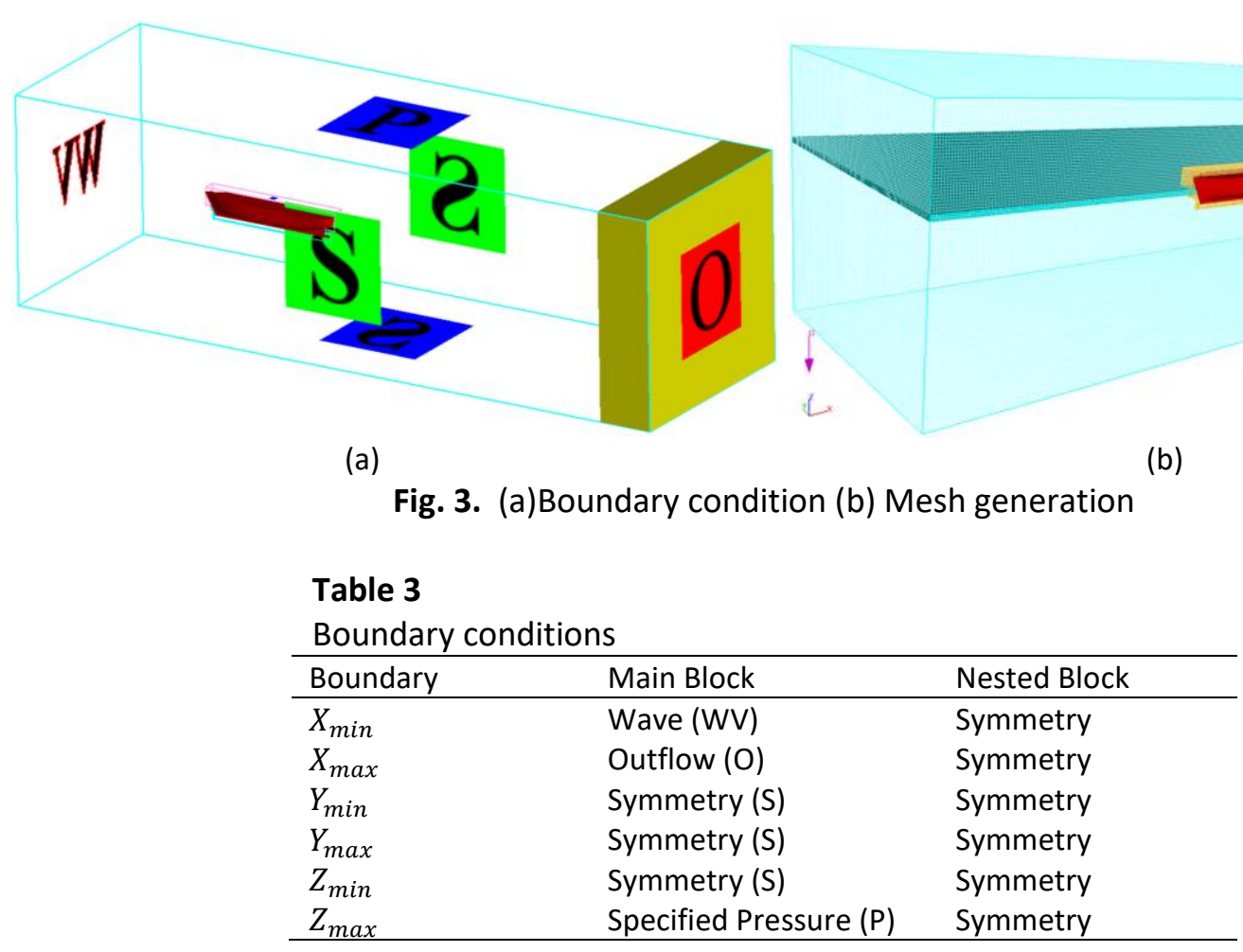

Table 4

Mesh independent study at $V s=4.630 \mathrm{~m} / \mathrm{s}$ and $\lambda=1.75 \mathrm{~L}$

\begin{tabular}{clll}
\hline \multirow{2}{*}{ Case } & \multirow{2}{*}{ Total Number of Cell } & \multicolumn{2}{c}{ Amplitude } \\
\cline { 3 - 4 } & & Heave Motion, $\mathrm{m}$ & Pitch Motion, deg \\
\hline$A$ & $2,098,566$ & 0.2683 & 2.5768 \\
$B$ & $2,961,938$ & 0.2373 & 2.3820 \\
$C$ & $4,083,085$ & 0.2260 & 2.2585 \\
$D$ & $5,809,868$ & 0.2272 & 2.2421 \\
\hline
\end{tabular}
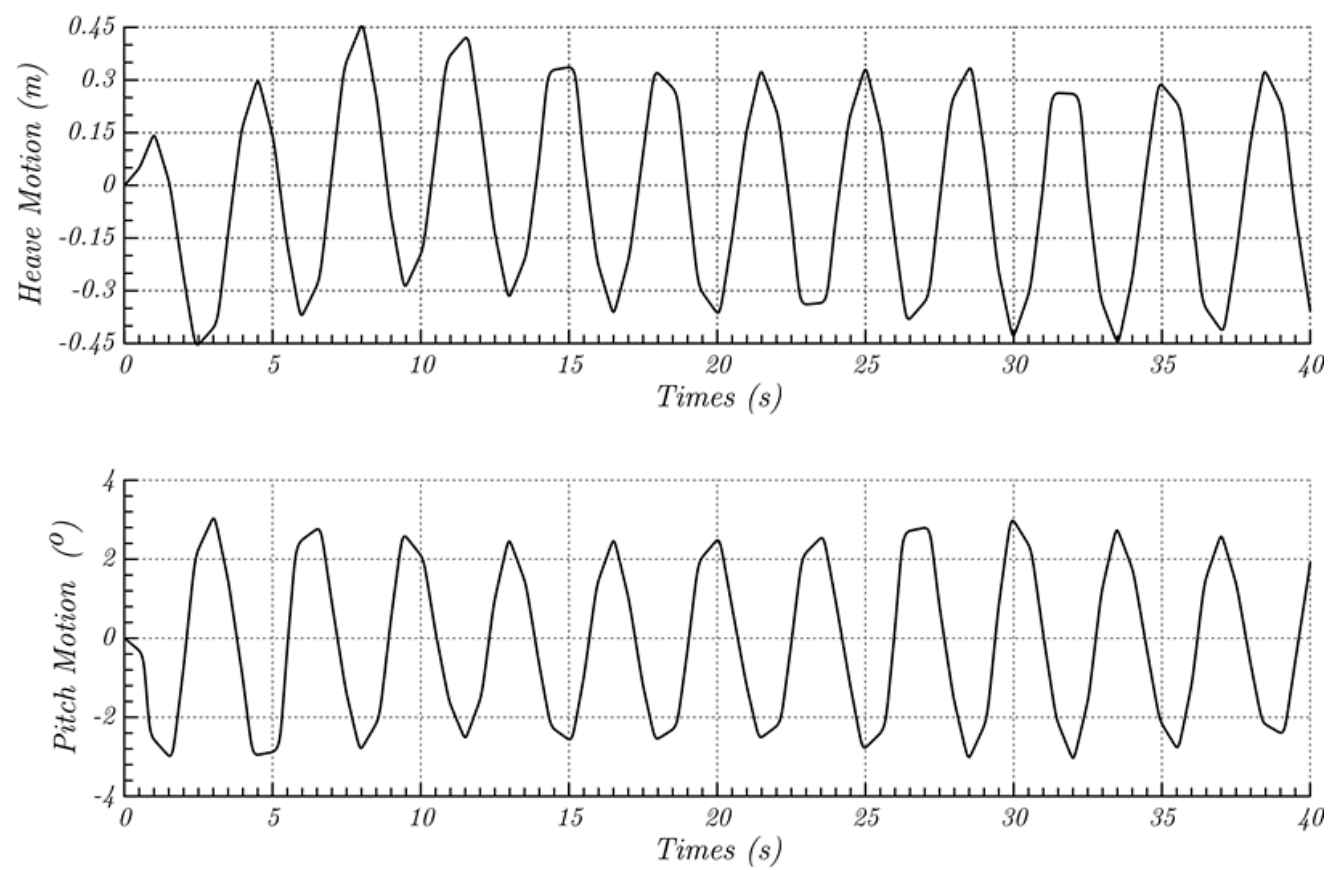

Fig. 4. Time history of heave and pitch motions characteristics of a training ship at $V s=$ $4.630 \mathrm{~m} / \mathrm{s}$ and $\lambda=1.75 \mathrm{~L}$ 

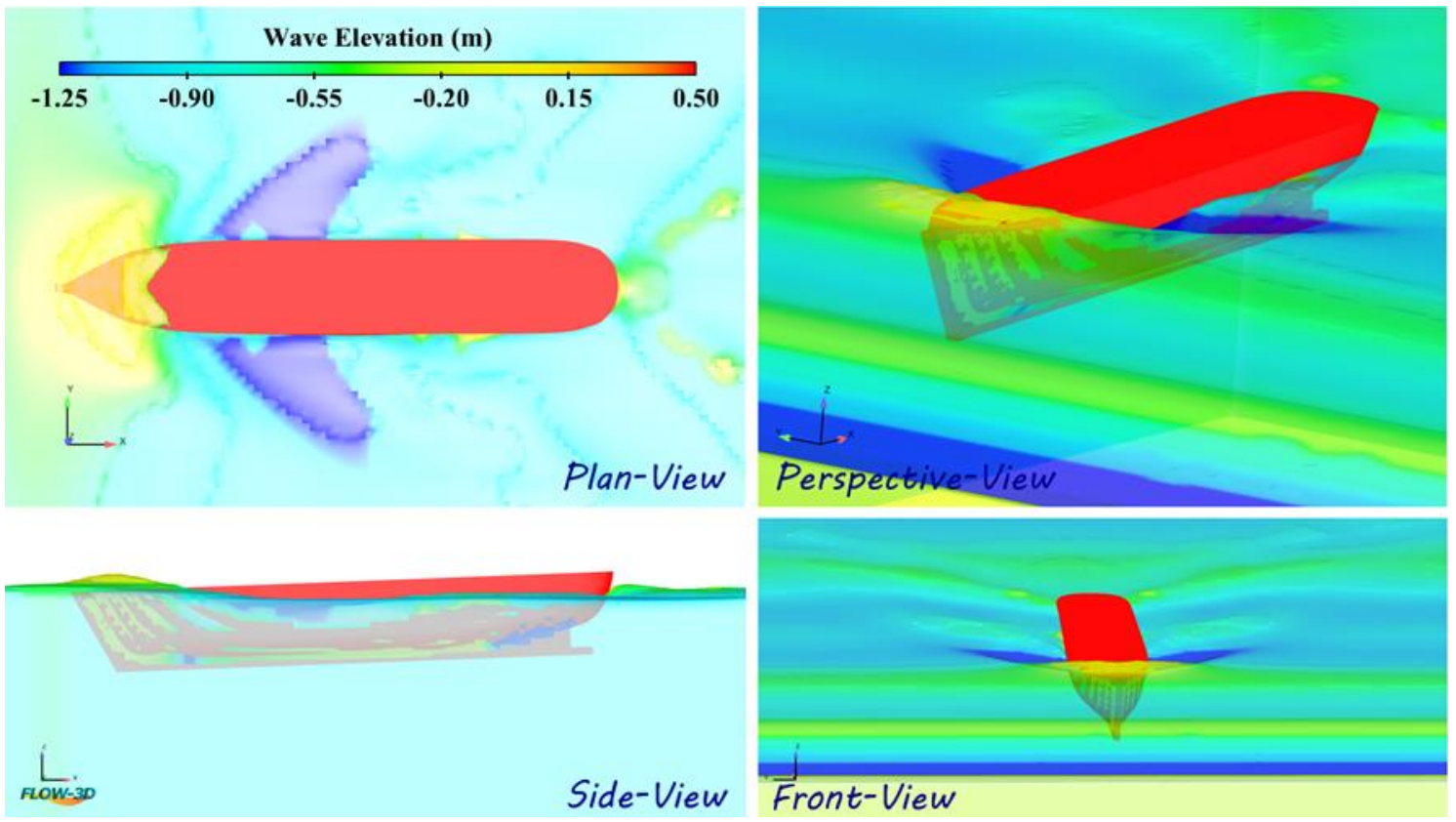

Fig. 5. Example visualisation of training ship at $v=4.630 \mathrm{~m} / \mathrm{s}$ and $\lambda=1.75 \mathrm{~L}$

\section{Results and Discussion}

\subsection{Seakeeping of a Training Ship at Various Wavelengths, $(\lambda)$}

The RAO characteristics for the heave and pitch motions of the training ship were shown in Figure 6. Basically, the subsequent increase of wavelength within the range of $0.25 \leq \lambda / L \leq 1.0$ was insignificant influence to the RAO magnitude for heave and pitch motions of the training ship, which inherently led to have a better seakeeping quality in seaway. This can be explained by the fact that the vertical motions of the training ship have not been deteriorated indicated by the small heave and pitch motions as clearly seen in Figures $7(a),(b)$ and (c). Referring to Table 5 , the subsequent increase of the wavelength from $\lambda=1.25 \mathrm{~L}$ to $1.5 \mathrm{~L}$ resulted in much more significant influence for the heave motion than her pitch motion. Here, the maximum increment has reached by $95 \%$; while her pitch motion amplitude increased by $76 \%$. This finding was similar to what was found by Hizir et al., [27] and Fitriadhy \& Adam [12], this can be explained by the fact that the resonant frequency occurred which is attributed to the lack of damping coefficient of the training ship. This situation can be visually described by the increase of her bow volume immersion as clearly displayed in Figure 7(d), (e) and (f).
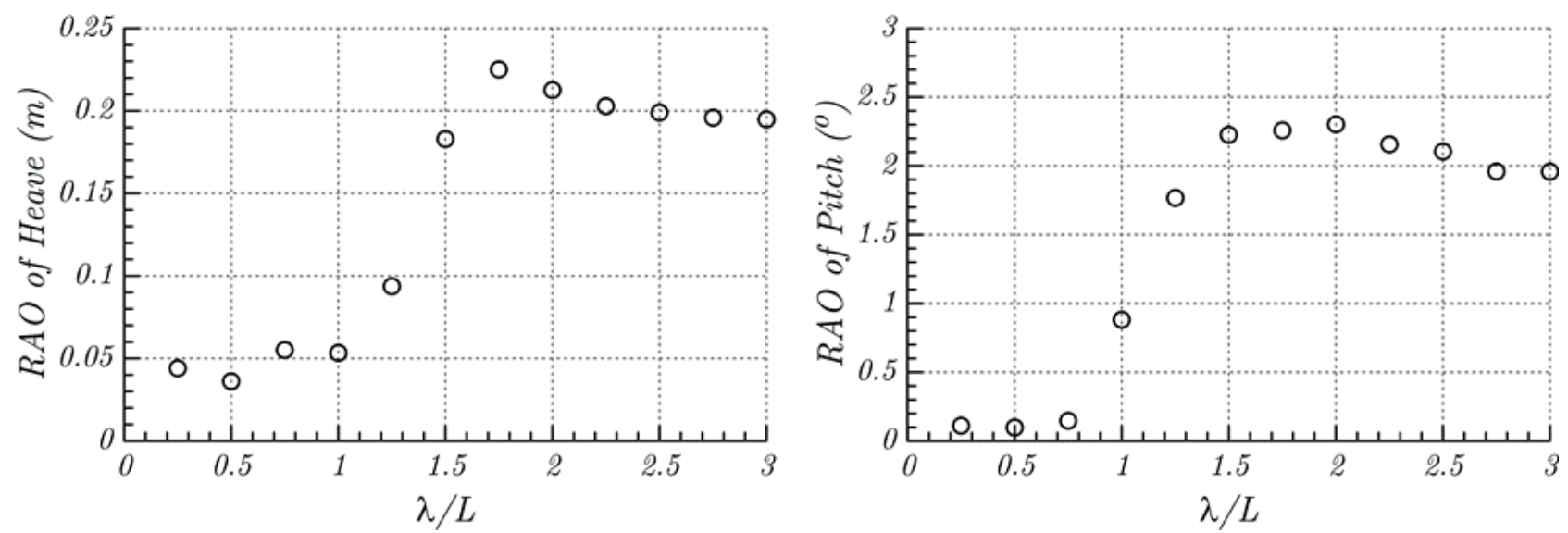

Fig. 6. RAO of heave and pitch motions at various wavelengths with $V s=4.630 \mathrm{~m} / \mathrm{s}$ (head-seas condition) 
Table 5

Heave and pitch motions of training ship at various wavelengths with $V s=4.630 \mathrm{~m} / \mathrm{s}$ (head-seas condition)

\begin{tabular}{lll}
\hline$\lambda / \mathrm{L}$ & Heave motion, $\mathrm{m}$ & Pitch motion, deg \\
\hline 0.25 & 0.0439 & 0.1112 \\
0.50 & 0.0361 & 0.1078 \\
0.75 & 0.0551 & 0.3468 \\
1.00 & 0.0533 & 0.8813 \\
1.25 & 0.0937 & 1.7665 \\
1.50 & 0.1829 & 2.2255 \\
1.75 & 0.2260 & 2.2585 \\
2.00 & 0.2126 & 2.3023 \\
2.25 & 0.2028 & 2.1571 \\
2.50 & 0.1989 & 2.1043 \\
2.75 & 0.1958 & 1.9586 \\
3.00 & 0.1948 & 1.9576 \\
\hline
\end{tabular}

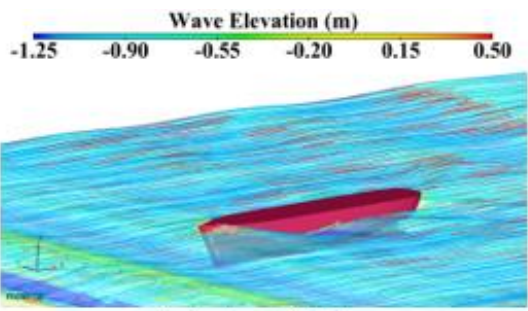

(a). $\lambda=0.25 \mathrm{~L}$

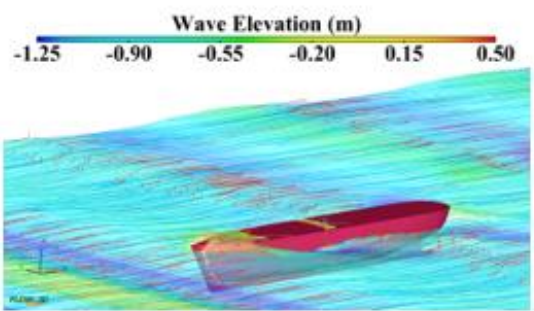

(d). $\lambda=1.0 \mathrm{~L}$

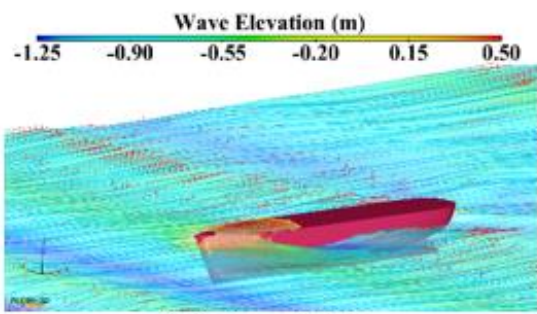

(g). $\lambda=1.75 \mathrm{~L}$

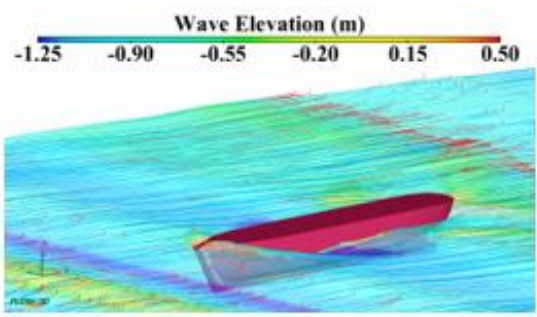

(k). $\lambda=2.50 \mathrm{~L}$

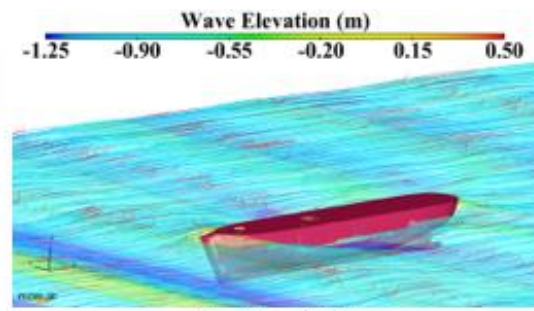

(b). $\lambda=0.5 \mathrm{~L}$

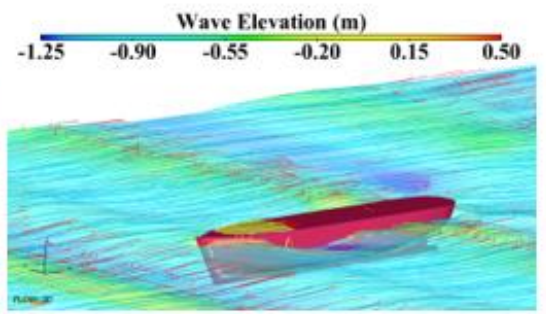

(e). $\lambda=1.25 \mathrm{~L}$

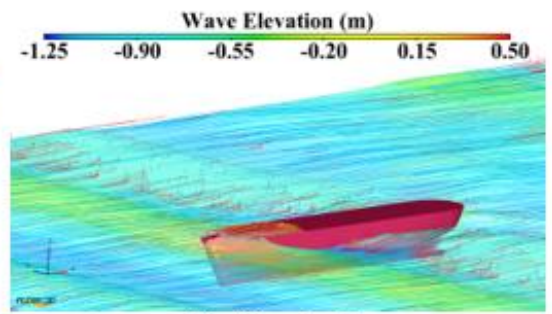

(h). $\lambda=2.0 \mathrm{~L}$

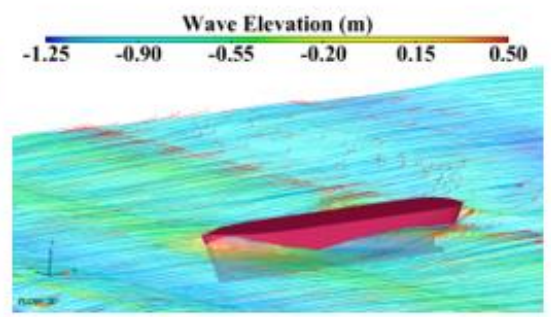

(i). $\lambda=2.75 \mathrm{~L}$

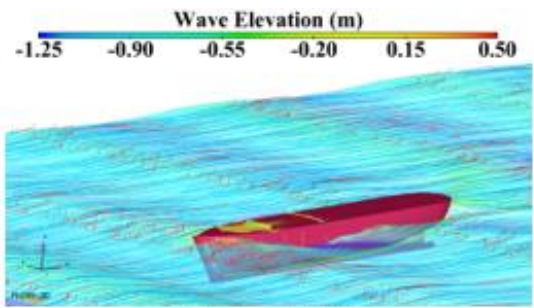

(c). $\lambda=0.75 \mathrm{~L}$

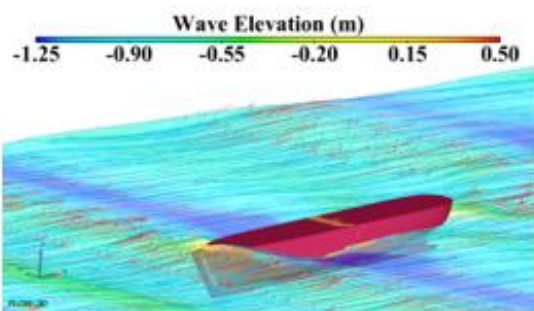

(f). $\lambda=1.50 \mathrm{~L}$

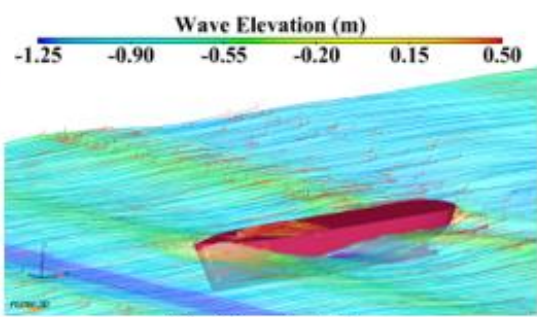

(i). $\lambda=2.25 \mathrm{~L}$

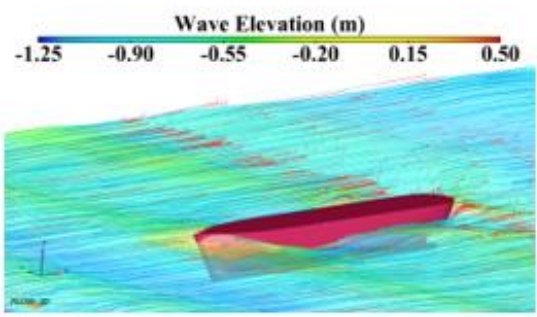

(j). $\lambda=3.0 \mathrm{~L}$

Fig. 7. Visualisation of wave elevation characteristics at various wavelengths ( $V s=4.630 \mathrm{~m} / \mathrm{s}$ ) 
In addition, the RAO of heave and pitch motions rapidly increased and ultimately reached the peak point at $\lambda=1.75 \mathrm{~L}$ and $\lambda=2.0 \mathrm{~L}$, respectively, as clearly displayed in Figure 6 (left) and Figure 6 (right), respectively. This condition was vulnerable to degrade the seakeeping performance of the training ship and might resulted in discomfortability to the crew on-board indicated by instantaneous sinkage and excessive trim of the training ship as shown in Figure $7(\mathrm{~g})$ and $(\mathrm{h})$. Furthermore, these motion responses were relatively steady or even reduced as the wavelength further increases by $3.0 \mathrm{~L}$ as clearly seen in Figures $7(i),(j),(k),(l)$ and $(m)$.

\subsection{Seakeeping of Training Ship in Various Speeds, (Vs)}

Figure 8 shows the RAO characteristics of heave and pitch motions of the training ship at various speeds. The magnitude of the heave and pitch motions are completely presented in Table 6. Basically, the training ship has qualitatively showed to have similar trend of the heave and pitch motions behaviours as the subsequent increase of the forward velocity. Regardless of the increase of the forward velocities, the results revealed that the training ship has good seakeeping performance within the range of $0.25 \leq \lambda / L \leq 1.0$. Similar to what was found by Hizir et al., [27], the highest forward velocity $(5.607 \mathrm{~m} / \mathrm{s})$ resulted in better seakeeping behaviour of the training ship indicated by the lower RAO of the heave $(0.25 \leq \lambda / L \leq 1.5)$ and pitch $(0.25 \leq \lambda / L \leq 1.75)$ motions as clearly seen in Figure 8 (left) and Figure 8 (right), respectively. However, the training ship has finally reached the maximum RAO of the heave and pitch motions as the further increase of $\lambda / L$ by $1.75 \mathrm{~L}$ and $2.0 \mathrm{~L}$, respectively. It should be noted here that the highest forward speed of the training ship has possibly led to downgrade her seakeeping performance indicated by the higher amplitude of the vertical motions. Referring to Table 6 , the training ship associated with $V s=5.607 \mathrm{~m} / \mathrm{s}$ and $\lambda=1.5 \mathrm{~L}$ resulted in the significant reduction of the heave motion $40.6 \%$ and $14.6 \%$; whilst, the heave motion has decreased by $21.8 \%$ and $16.6 \%$ as compared to the forward speed of $3.603 \mathrm{~m} / \mathrm{s}$ and $4.630 \mathrm{~m} / \mathrm{s}$, respectively. However, the RAO of her pitch motion subsequently increased, which was proportional to the forward speeds in the region of $\lambda \geq 2.0 \mathrm{~L}$. The examples clearly presented in Figure 9 with the ratio of wavelength is $2.5 \mathrm{~L}$. The computational analysis showed that the subsequent increase of the forward speed incorporated with the coupling motion in the head-sea is predominantly heave into pitch, so that there can be a more significant influence on the occurrence of the pitch motion responses than the heave motion. This can be explained by the reasons that the training ship was easy to pitch, where the height of water on deck is sensitive to pitch angle as shown in as shown in Figure 9(a), (b) and (c). This inherently indicated that the seakeeping performance of the training ship has gradually degraded. Similar to the heave motion behaviour, the RAO of the pitch motion for the training ship was then relatively steady; even tends to decrease especially at the range of $2.0 \leq \lambda / L$ $\leq 3.0$.
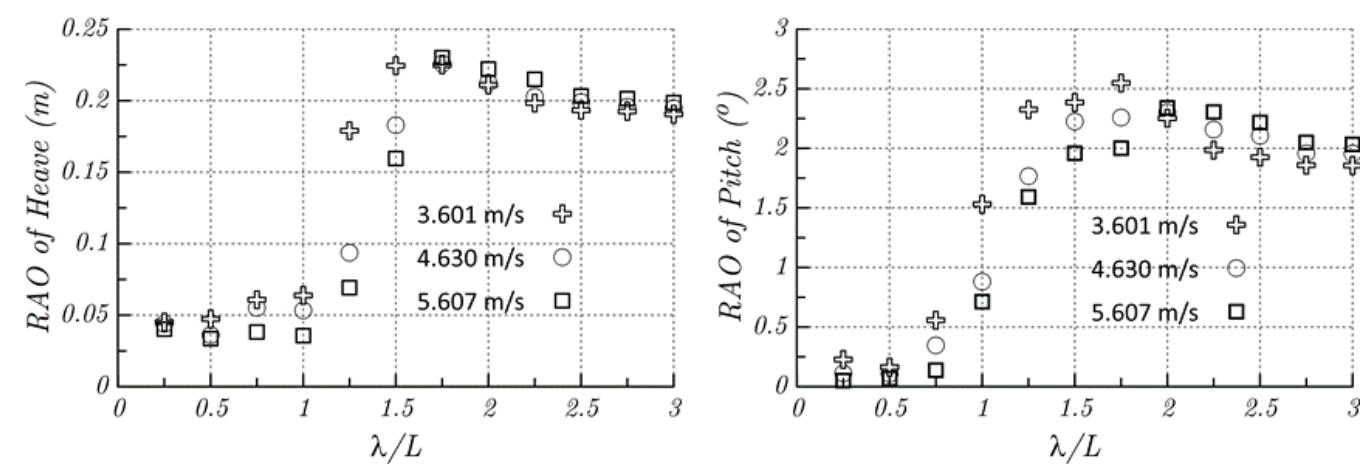

Fig. 8. RAO heave and pitch motions at various training ship's speeds 
Table 6

RAO of heave and pitch motions at various training ship's speeds

\begin{tabular}{lllllll}
\hline \multirow{2}{*}{$\lambda / \mathrm{L}$} & \multicolumn{3}{l}{ Amplitude of Heave motion, $\mathrm{m}$} & \multicolumn{3}{l}{ Amplitude of Pitch motion, deg } \\
\cline { 2 - 7 } & $3.601 \mathrm{~m} / \mathrm{s}$ & $4.630 \mathrm{~m} / \mathrm{s}$ & $5.607 \mathrm{~m} / \mathrm{s}$ & $3.601 \mathrm{~m} / \mathrm{s}$ & $4.630 \mathrm{~m} / \mathrm{s}$ & $5.607 \mathrm{~m} / \mathrm{s}$ \\
\hline 0.25 & 0.0452 & 0.0439 & 0.0402 & 0.2281 & 0.1112 & 0.0499 \\
0.50 & 0.0473 & 0.0361 & 0.0336 & 0.1640 & 0.1078 & 0.0670 \\
0.75 & 0.0607 & 0.0551 & 0.0382 & 0.5563 & 0.3467 & 0.1363 \\
1.00 & 0.0638 & 0.0533 & 0.0356 & 1.5299 & 0.8813 & 0.7122 \\
1.25 & 0.1789 & 0.0936 & 0.0692 & 2.3253 & 1.7665 & 1.5921 \\
1.50 & 0.2245 & 0.1829 & 0.1596 & 2.3855 & 2.2255 & 1.9584 \\
1.75 & 0.2250 & 0.2260 & 0.2301 & 2.5472 & 2.2585 & 2.0015 \\
2.00 & 0.2111 & 0.2126 & 0.2221 & 2.2522 & 2.3023 & 2.3402 \\
2.25 & 0.1984 & 0.2028 & 0.2149 & 1.9852 & 2.1571 & 2.3052 \\
2.50 & 0.1933 & 0.1989 & 0.2034 & 1.9246 & 2.1043 & 2.2171 \\
2.75 & 0.1925 & 0.1958 & 0.2015 & 1.8588 & 1.9585 & 2.0490 \\
3.00 & 0.1906 & 0.1948 & 0.1986 & 1.8553 & 1.9575 & 2.0325 \\
\hline
\end{tabular}

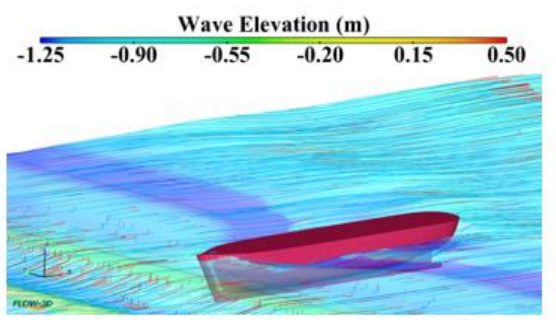

(a). $V s=3.601 \mathrm{~m} / \mathrm{s}, \lambda=2.5 \mathrm{~L}$

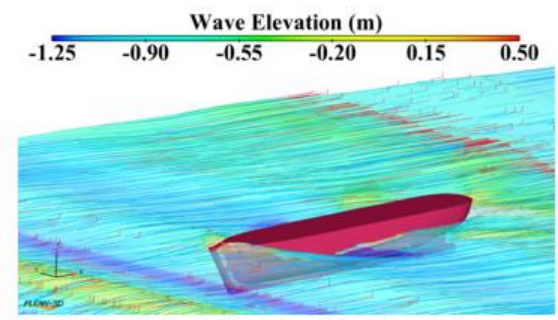

(b). $V s=4.630 \mathrm{~m} / \mathrm{s}, \lambda=2.5 \mathrm{~L}$

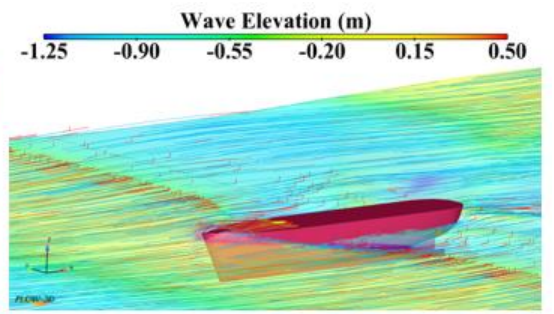

(c). $V s=5.607 \mathrm{~m} / \mathrm{s}, \lambda=2.5 \mathrm{~L}$

Fig. 9. Visualisation of wave elevation characteristics at various speeds (head-seas condition)

\subsection{Seakeeping of Training Ship in Following-Seas}

The characteristics of heave and pitch motions for the training in the following-seas is clearly displayed in Figure 10. In addition, the magnitude of the heave and pitch motions are completely presented in Table 7. In general, the CFD results revealed that the training ship's motions in the following-seas has the higher magnitude of the heave and pitch motions especially for $\lambda / L \leq 1.75$ when compared to the head-seas condition. Similar to what was explained by Kat $\&$ Thomas [28] the reason can be explained by the fact that a ship in the following seas could experience large speed fluctuations (at low encounter frequencies) about its mean forward speed. It was noted that the maximum increment of the heave and pitch motions in the following-seas condition were $66 \%$ and $68 \%$ at $\lambda / L=1.25$ and $\lambda / L=1.0$, respectively, as compared with case of the head-seas condition. Inherently, this may lead to the unfavourable and dangerous situations of the training ship in the following seaway. Correspondingly, the training ship has gradually undergone rigorous vertical motions in instantaneous trim indicated by the more immersion at her bow section as shown in Figure 11(a), (b) and (c). Merely, the training ship appeared to be vulnerable to surf-riding condition in the following seas through the increase of the vertical motions while riding on a wave crest. The further increase of the wavelength $(\lambda / L>1.75)$ has relatively resulted in the reduction the heave and pitch motions, which possibly provided more favorable ship's motions. Besides, the range of $\lambda / L \geq$ 2.0 has seemed to bear qualitative similarities both heave and pitch motions to the head-seas condition. 

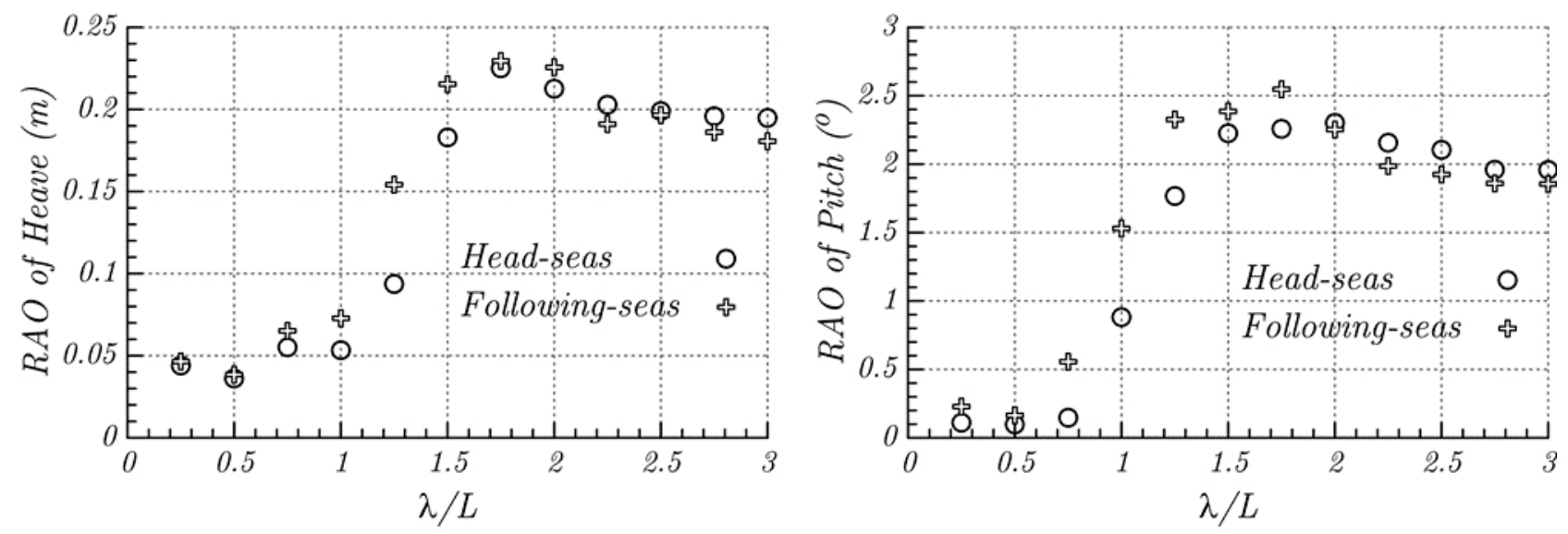

Fig. 10. RAO of heave and pitch motions at various wavelengths and wave directions with $V s=4.630 \mathrm{~m} / \mathrm{s}$

\section{Table 7}

Heave and pitch motions of training ship at various wavelengths with $V s=4.630 \mathrm{~m} / \mathrm{s}$ (following-seas condition)

\begin{tabular}{lll}
\hline$\lambda / L$ & Heave motion, $\mathrm{m}$ & Pitch motion, deg \\
\hline 0.25 & 0.0466 & 0.1245 \\
0.50 & 0.0385 & 0.1388 \\
0.75 & 0.0652 & 1.1099 \\
1.00 & 0.0728 & 1.4792 \\
1.25 & 0.1542 & 2.3524 \\
1.50 & 0.2154 & 2.4263 \\
1.75 & 0.2295 & 2.5309 \\
2.00 & 0.2257 & 2.4522 \\
2.25 & 0.1911 & 2.2183 \\
2.50 & 0.1966 & 1.9579 \\
2.75 & 0.1862 & 1.8742 \\
3.00 & 0.1807 & 1.8739 \\
\hline
\end{tabular}

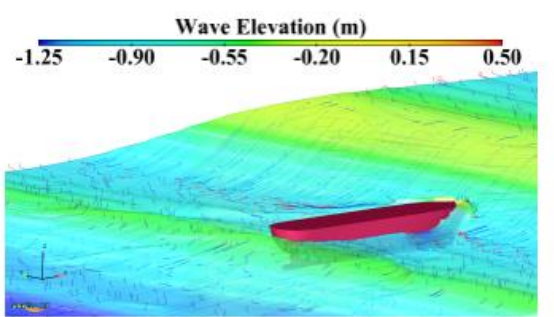

(a). $\lambda=1.5 \mathrm{~L}$

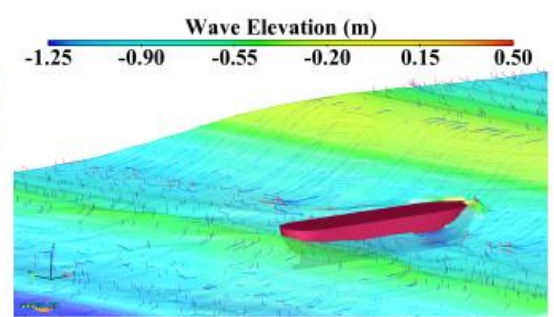

(b). $\lambda=1.75 \mathrm{~L}$

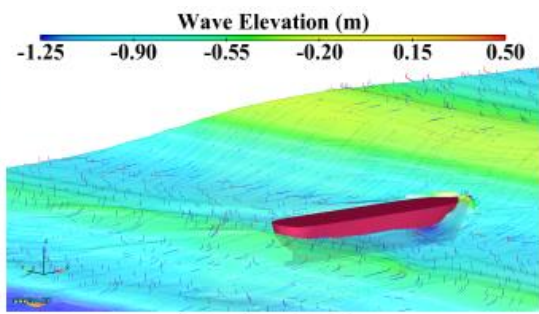

(c). $\lambda=2.0 \mathrm{~L}$

Fig. 11. Visualisation of wave elevation characteristics at various wavelengths with $V s=4.630 \mathrm{~m} / \mathrm{s}$ (followingseas condition)

\section{Conclusion}

The seakeeping investigation into heave and pitch motion of the training ship at various wavelengths, wave directions, and forward speeds have been successfully performed using the Computational Fluid Dynamic (CFD) approach. The computational simulation results are then presented in the form of her Responses Amplitude Operator (RAO) i.e., heave and pitch motions. The computational simulation results can be drawn as follows:

i. The subsequent increase of wavelength ( $\lambda \leq 1.0 \mathrm{~L})$ has insignificant influence on the seakeeping quality of the training ship in seaway indicated with the less RAO values of the 
heave and pitch motions responses. has led to the increment of heave and pitch motion of the training ship which leads to downgrade of the seakeeping performance. However, the training ship experiences more excessive heave and pitch motions at $1.25 \leq \lambda \leq 1.5$, which is inherently degrade her seakeeping performance.

ii. In the following-seas, the heave and pitch motions of the training ship are higher than the head-seas condition by $66 \%$ and $68 \%$ at $\lambda=1.25 \mathrm{~L}$ and $1.0 \mathrm{~L}$, respectively.

iii. In general, the increase of the forward speed resulted in better seakeeping behavior of the training especially within the range of $0.25 \leq \lambda / L \leq 1.0$. Inversely, the training ship motions has been deteriorated indicated by the significant increase of the RAO for the heave and pitch motions.

iv. The RAO of the heave and pitch motions for the training ship are relatively steady; even tends to decrease especially at the range of $2.0 \leq \lambda / L \leq 3.0$.

\section{References}

[1] RYU, Kyung-Jin, Tae-Sun PARK, Chang-Woo KIM, and Tae-Geun PARK. "A study on the development of multipurpose fisheries training ship and result of seakeeping model test." Journal of the Korean Society of Fisheries and Ocean Technology 55, no. 1 (2019): 74-81.

https://doi.org/10.3796/KSFOT.2019.55.1.074

[2] Cho, Jang-Won, and Chang-Hee LEE. "A Study on the improvement for Basic. Advance Safety Training CourseFocusing on the Crew's Fire Fighting Training." Journal of Fisheries and Marine Sciences Education 28, no. 2 (2016): 417-427. https://doi.org/10.13000/JFMSE.2016.28.2.417

[3] Han, Seung-Jae, Seung-Chul Lee, Young-Rok Ha, lee-Gyu Jeong, and In-Chul Kim. "A Study on the Improvement of MSI by Ship Hull Form Modification of the Training Ship." Journal of Fisheries and Marine Sciences Education 26, no. 4 (2014): 686-694. https://doi.org/10.13000/JFMSE.2014.26.4.686

[4] Han, Seung-Jae, Young-Rok Ha, Seung-Chul Lee, Chang-Woo Lee, and In-Chul Kim. "A Study on Motion Sickness Incidence due to Changes in the Speed of the Training Ship Kaya." Journal of the Korean Society of Marine Environment \& Safety 20, no. 2 (2014): 228-233.

https://doi.org/10.7837/kosomes.2014.20.2.228

[5] Kim, Dong Jin, Sun Young Kim, Young Jun You, Key Pyo Rhee, Seong Hwan Kim, and Yeon Gyu Kim. "Design of highspeed planing hulls for the improvement of resistance and seakeeping performance." International Journal of Naval Architecture and Ocean Engineering 5, no. 1 (2013): 161-177.

https://doi.org/10.2478/IJNAOE-2013-0124

[6] Siddiqui, Mohd Atif, Marilena Greco, C. Lugni, and O. M. Faltinsen. "Experimental studies of a damaged ship section in beam sea waves." Applied Ocean Research 97 (2020): 102090.

https://doi.org/10.1016/i.apor.2020.102090

[7] Yao, Chao-Bang, Xiao-Shuai Sun, Wei Wang, and Qing Ye. "Numerical and experimental study on seakeeping performance of ship in finite water depth." Applied Ocean Research 67 (2017): 59-77.

https://doi.org/10.1016/j.apor.2017.06.005

[8] Habekost, Tim, Sven Handschel, Daniel Beyer, Klaas Oltmann, and Moustafa Abdel-Maksoud. "Experimental and Numerical Seakeeping Analysis of a Mobile Offshore Application Barge (MOAB $\left.{ }^{\circledR}\right)$." In The Twenty-second International Offshore and Polar Engineering Conference. International Society of Offshore and Polar Engineers, 2012.

[9] Wang, S. M., S. Ma, and W. Y. Duan. "Seakeeping optimization of trimaran outrigger layout based on NSGAII." Applied Ocean Research 78 (2018): 110-122.

https://doi.org/10.1016/i.apor.2018.06.010

[10] Lin, Yu-Hsien, and Chia-Wei Lin. "Numerical Simulation of Seakeeping Performance on the Preliminary Design of a Semi-Planing Craft." Journal of Marine Science and Engineering 7, no. 7 (2019): 199. https://doi.org/10.3390/imse7070199

[11] Bi, Xiaosheng, Hailong Shen, Jin Zhou, and Yumin Su. "Numerical analysis of the influence of fixed hydrofoil installation position on seakeeping of the planing craft." Applied Ocean Research 90 (2019): 101863. https://doi.org/10.1016/i.apor.2019.101863 
[12] Fitriadhy, A., and N. Amira Adam. "Heave and pitch motions performance of a monotricat ship in headseas." International Journal of Automotive and Mechanical Engineering 14 (2017): 4243-4258. https://doi.org/10.15282/ijame.14.2.2017.10.0339

[13] Mancini, Simone, Ermina Begovic, Alexander H. Day, and Atilla Incecik. "Verification and validation of numerical modelling of DTMB 5415 roll decay." Ocean Engineering 162 (2018): 209-223. https://doi.org/10.1016/i.oceaneng.2018.05.031

[14] Chen, Hao, Ling Qian, Zhihua Ma, Wei Bai, Ye Li, Derek Causon, and Clive Mingham. "Application of an overset mesh based numerical wave tank for modelling realistic free-surface hydrodynamic problems." Ocean Engineering 176 (2019): 97-117. https://doi.org/10.1016/i.oceaneng.2019.02.001

[15] Sapee, S. "Computational Fluid Dynamics Study on Droplet Size of Kerosene Fuel." Journal of Advanced Research in Fluid Mechanics and Thermal Sciences 16, no. 1 (2015): 1-14.

[16] Hirt, C. W., and B. Nichols. "Flow-3D User's manual." Flow Science Inc 107 (2013).

[17] Maki, Kevin J., Riccardo Broglia, Lawrence J. Doctors, and Andrea Di Mascio. "Numerical investigation of the components of calm-water resistance of a surface-effect ship." Ocean engineering 72 (2013): 375-385. https://doi.org/10.1016/j.oceaneng.2013.07.022

[18] Yan, S., and G. Huang. "Dynamic performance of towing system-Simulation and model experiment." In Proceedings, OCEAN, vol. 96. 1996.

[19] Fitriadhy, Ahmad, Nur Adlina Aldin, and Nurul Aqilah Mansor. "CFD Analysis on Course Stability of a Towed Ship Incorporated with Symmetrical Bridle Towline." CFD Letters 11, no. 12 (2019): 88-98.

[20] Fitriadhy, Ahmad, Nurul Aqilah Mansor, Nur Adlina Aldin, and Adi Maimun. "CFD Analysis on Course Stability of An Asymmetrical Bridle Towline Model of a Towed Ship." CFD Letters 11, no. 12 (2019): 43-52.

[21] Fitriadhy, A., and A. M. A. Malek. "Computational fluid dynamics analysis of a ship's side launching in restricted waters." Journal of Mechanical Engineering and Sciences 11, no. 4 (2017): 2993-3003. https://doi.org/10.15282/imes.11.4.2017.3.0269

[22] Fitriadhy, A., M. A. Faiz, and S. F. Abdullah. "Computational fluid dynamics analysis of cylindrical floating breakwater towards reduction of sediment transport." J. Mech. Eng. Sci. 11, no. 4 (2017): 3072-3085. https://doi.org/10.15282/imes.11.4.2017.10.0276

[23] Yakhot, Victor, and Steven A. Orszag. "Renormalization group analysis of turbulence. I. Basic theory." Journal of scientific computing 1, no. 1 (1986): 3-51. https://doi.org/10.1007/BF01061452

[24] Yakhot, A., S. Rakib, and W. S. Flannery. "Low-Reynolds number approximation for turbulent eddy viscosity." Journal of scientific computing 9, no. 3 (1994): 283-292. https://doi.org/10.1007/BF01575033

[25] Koutsourakis, Nektarios, John G. Bartzis, and Nicolas C. Markatos. "Evaluation of Reynolds stress, k- $\varepsilon$ and RNG k- $\varepsilon$ turbulence models in street canyon flows using various experimental datasets." Environmental fluid mechanics 12 , no. 4 (2012): 379-403. https://doi.org/10.1007/s10652-012-9240-9

[26] Li, Binbin, Zhenhua Huang, Ying Min Low, and Jinping Ou. "Experimental and numerical study of the effects of heave plate on the motion of a new deep draft multi-spar platform." Journal of marine science and technology 18, no. 2 (2013): 229-246. https://doi.org/10.1007/s00773-012-0203-0

[27] Hizir, Olgun Guven, Zhiming Yuan, Atilla Incecik, and Osman Turan. "The effect of forward speed on nonlinear ship motion responses." In 18th International Conference on Ships and Shipping Research, pp. 1-10. 2015.

[28] Vassalos, D., M. Hamamoto, A. Papanikolaou, and D. Molyneux. "Broaching and capsize model tests for validation of numerical ship motion predictions." Contemporary Ideas on Ship Stability (2000): 69.

https://doi.org/10.1016/B978-008043652-4/50007-9 